\title{
Cultural Politics and Education in Ethiopia: A Search for a Viable Indigenous Legend
}

\author{
Mohammed Girma \\ Research Associate, School of Religious Studies, University of the Free State, Bloemfontein \\ South Africa andVisiting Scholar, Yale University \\ Billitonstraat 12, 2585 TZ, The Hague, the Netherlands \\ E-mail: telosgm@gmail.com
}

Received: November 24, 2011

Accepted: December 22, 2011 Published: March 1, 2012

doi:10.5539/jpl.v5n1p117

URL: http://dx.doi.org/10.5539/jpl.v5n1p117

The research is financed by Jagtspeolfonds in the Netherlands.

\begin{abstract}
The history of modern education in Ethiopian is short. What is not so short, however, is the history of traditional education, temehert. It goes back as far as the introduction of Christianity to Ethiopia - fourth century EC. Since its inception, education had a close, if ambivalent, relationship with different ideological tenets, and each tenet trying to formulate its educational philosophy around its own unique narrative. While some narratives arose from indigenous legend, others are imported (and domesticated in some cases) from abroad. In this essay, I do not intend to discuss educational policies per se. I, however, intend to show how a deliberate, or unwitting, de-link with indigenous legend would affect the trajectory, and also the success, in educational system in Ethiopia. After a brief paradigmatic characterization of two ideologies and their underlying narratives, I will critically unravel the ethno-federalism educational philosophy of Ethiopian People's Revolutionary Democratic Front (EPRDF) and its undergirding ethnic legends. I focus on ethno-federalist system because it is an incumbent philosophy. After discussing a nascent remedy proposed by MaimireMennasemay, vis,.the notion of tezeta, I intend to argue for the primacy of the notion of qal-kidan as a better alternative. I will base my argument on the cultural prevalence, but also conceptual credibility.
\end{abstract}

Keywords: Education, Politics, Ethiopia, Tezeta, Qal-kidan, EPRDF

\section{Education and Ideology: A Brief Background}

Education was (is still) taken in Ethiopia as a hermeneutical journey. Both the State and the church, especially the Ethiopian Orthodox Church (EOC), were aware of the fact that education involves providing students with interpretive tools to understand reality surrounding them. However, unlike scientifically positioned hermeneutical methods which aim to avoid defined biases, the educational hermeneutic in Ethiopia was and is willing to embrace intentional biases, pre-conceived assumptions and pre-determined outcomes. This is because the trajectory and the outcome of education are supposed to be true to the established legend or imported ideological narrative. I will here discuss traditional educational system (also known as Ye KoloTemhert Bet) and the educational system under the Dergue (Ethiopian Marxist regime). The former takes indigenous legend as the point of departure. The legend in this educational paradigm is that Ethiopia is a 'Christian island' and the nation of covenant. Accordingly, largely dependent on the church for educated man power, the monarchs during this time also intended to produce 'god-fearing' individuals. In fact, the biblical verse 'The Fear of God is the Beginning of Wisdom' was a well-known maxim of traditional school.

This schooling system has some remarkable success stories: architected of Fasilidas in Gonder, basilica of Axum, unique literary system, inimitable alphabet and number, the art of St. Yared and the philosophy of Zar'aYaeqobhavetheir roots in this system (Mercier 2001: 45-6). Besides, it built one of the oldest nation states in the world, and formulated fluid and functional bureaucracy. Socially, it created and maintained highly regarded social norms and ethical concepts such as fereha-egziabiher (fear of God). However, this early promise of innovativeness was not sustained. The reason for the discontinuity of this innovation, I have to concede, is contentious. Nevertheless, I, in what follow, will try to delineate the reason for the discontinuity of innovative attitudefrom a philosophical point of view.That is, as time goes on, the 'fear of God' in this philosophical paradigm 
was mainly understood as a strict spiritual discipline, especially, exhibiting little or no interest in the material order. Tigab (satiety), therefore, was taken as a sign of rebellion against the divine order. The schooling system and conditions were tuned in such a way as to equipstudents to insulate themselves from the pursuit of material wealth (Bushell 2002: 553).

Albeit this kind of educational philosophy can be rooted in a certain theological interpretation of creation, dualistic understanding of reality however was rooted in Greek (especially) Platonic philosophy. In facr, Greek philosophy was a significant part of theological teaching of the church. This is because, for one, historically, it was the Alexandrian church which gave birth to the EOC. It is well documented that the Alexandrian church embraced Platonic philosophy as a conceptual tool to formulate its theology. The consequence of this relationship was even more deepened by the fact that the Abun (the head of the church) was directly sent from Alexandria for almost fifteen centuries. However, the main Greek philosophical impact comes from the translation of Greek literature of both theological and philosophical nature (Ference 1985: 258-260). Notable of such translations wasAngara Falasfa (the book that includes the sayings of Greek philosophers including Socrates, Aristotle and Plato). Angara Falasfa, needless to say, is one of the important texts taught in Ye KoloTemhert-Bet - traditional Church schools.

As a result, dualistic epistemology became almost a standard philosophical framework to understand reality. What is deemed to be 'sacred' and 'material' was strongly dichotomized often with a stark preference to the former. With an exception of politics - which was assimilated to the sphere of the 'sacred' based on the legend that kings are 'anointed' by God and that Ethiopia is a covenant nation - any academic inquiry into the 'secular' domain was considered as tampering with the spiritual order. Students, therefore, are carefully coached to lead ascetic life in monasteries as opposed to engaging the material world and pursuing innovation. They are encouraged to beg, rather than work, not necessarily because they are needy, but as a part of spiritual discipline and a means of 'disowning' their souls from 'this world'(Chaillot 2002: 97).

Conscious of the fact that traditional educational system was unable to make Ethiopia compete in a global stage, Emperor Haile Selassie decided to abandon the legend (at least in relation to education) and join the global chorus of modernization. He, accordingly, established two institutions: RasTafari Secondary School and Haile Selassie I University College. As opposed to the ascetictendency of the traditional schools, these modern schools started to produce students in the area of agriculture, laboratory science and teaching training (Tekeste 2006: 12). However, despite some notable success, the educational philosophy did not have a narrative that resonates to the culture and Ethiopian way of life. This is because, as TekesteNegash argues, the curriculum did not have a coherent strategy, and it was based on ad hoc teaching system 'left to teachers who came from different countries with different backgrounds'(Tekeste 2006: 12). In the meantime, the legend which was deeply engrained in Ethiopian culture and way of thinking was used as a means of repression to maintain the status quo rather than mobilize young minds for innovative revolution.

The Marxist regime, which overthrew the feudalist system, took even more dramatic leap in rejecting religiously laden indigenous legend than its predecessor. Exorcizing any religious element from a wide array of social and economic activities of Ethiopian life, it aimed to define reality in a morematerialistic term. Fascinated by the ideology of the 'Eastern Block', the regime as well as the young and educated laid out the quest of 'new religion' in the form of Marxism-Leninism (Messay 2002: 1-2). This radical change of philosophy vis-à-vis education (among many other sectors) was triggered, according to MessayKebede, by inner contradiction of Haile Selassie's regime. By that what he means is that, on the one hand, in order to join the global chorusof modernization the emperor portrayed himself as a reformer and pacesetter. On the other hand, however, in order to maintain traditional authority and oligarchic interest, the emperor was inclined to subscribe to repressive methods (Messay 2002: 13).

The student movement coupled with military coup was able to bring an end to Solomonic dynasty, but also with it, to a social system impregnating an educational philosophy. In a stark contrast to the previous system which emphasized 'divine wisdom' over against the scientific one, the Dergue (committee constituting the Marxist regime) came up with new adage - 'putting the nature under control'. The tool to do so was considered to be science and reason. However, what the Derguedid notput into considerationwas that science and reason require freedom to think, create and express. Conversely, as William Saint, a Lead Educational Specialist of African Region in World Bank, pointed out, the Dergue started to expand its surveillance to intrude in academic affairs, repress dissents, forcing Marxism as a mandatory course and prohibiting student organizations. This, according to Saint, resulted in withered intellectual life, isolated educational system and soaring brain drain (Saint 2004: 83-113). There however seems to be more behind the dire performance of educational institutions and failure to bring about the much needed modernization than the repressive nature of the Dergue: the rigidly scientifically oriented approach and disregard to the cultural currents. In other words, despite creating temporary euphoria among the ordinary citizens by abolishing class system, the Marxist ideology did not connect to the indigenous legend and narrative, and therefore, its 
narrative of modernization did not resonate with the mass.

\section{Etho- Federalism and Education as a Search for Primordial Self}

The EPRDF, after overthrowing the Dergue, came up with the educational paradigm that radicalise neither religiously created legend nor secularisation. Rather, it gambled on ethnicity as a way of formulating a new narrative. Unlike the Dergue which imported a totally alien philosophy (Marxism) from abroad, EPRDF integrated ethnicity with elements pertaining to postmodernist thinking. I elsewhere called this as a 'paradigm of compartmentalization' (Girma 2010: 109-51). In this section, I discuss the questions of how far the compartmentalizing narrative, which also integrates some postmodernist thinking, can provide with a viable narrative that is true to the culture, and yet, trigger much needed social change and development. I will discuss some aspects of the postmodern view on education and show how far they also characterize the present system of education in Ethiopia.

Education is often taken as an indispensable tool for modernization and a key for progress. In order to achieve this modern education uses three vital 'interpolations': individualization, futurism and secularization. Individualization is seen as ahelpful tool to formulate moral and political rights and obligations while futurism coupled with rationality is used to bring about inevitable and relentless progress. Secularization, on the other hand, is a mechanism which prevents a possible relapse to traditional religious dogmatism (Marrow \& Torres 1995: 409).

Albeit some 'progressive postmodernists' might be inclined to espouse some elements of the modernist tools, hard-line postmodernists however try to subvert them. Their main intention is not maintaining the traditional way of thinking. It rather is deconstructing them in light of formulating 'emancipatory' and 'critical' pedagogy (Levinson 2002: 607). Their fundamental goal is seeing themselves as advocates to ethnic minorities by upsetting incumbent social and political structures. This is where the ethno-federalist approach to education in Ethiopia converges with postmodernist thinking: they both claim to make the issues of ethnic minority an important part of their moral discourse. As a way of achieving this, the ethno-federalist system puts forward a policy to use ethnic languages as the medium of education, even despite the absence of sufficient academic resources (both human and material). The implication is that forcing the use of vernacular as a medium of education is more of a political move than a pedagogical one (Moges 2010: 23-24). Far from being independent, education then becomes an important part of cultural and ethnic politics (Usher \& Edwards 1994: 215).

In the same vein with postmodernism, the ethno federalist system focuses on the dark side of metanarrative. The notion of unity therefore is not positively understood. In fact, any notion of national unity and metanarrative are associated with repression of the minorities. Meanwhile, the system, like postmodernist school, focuses on endless deferrals of social promise and ethnic self-determination. In ethno-federalist system, the notion of free individual as a possessor of natural right and autonomy is as good as dead. This is precisely because, far from being free, individual is positioned as a decentred, fragmented, gendered and classed subject (Clegg \& Hardy: 1999: 189).

The way I see it, in the ethno-federalist system and the characteristics its educational system striking resemblance to elements of postmodern thinking. Firstly, the educational system is designed not to promote independent thinking. It is resolutely envisioned to subvert overarching and inclusive indigenous legend and re-orientate students to their respective ethnic pasts. This is undertaken by pushing the use of ethnic languages as medium of education thereby promoting 'exclusivist' sense of solidarity within them. This is meant to bolster a new political system - ethnic federalism, which has two things at its centre: (re)invigorating social and cultural nostalgia and (re)activating the pain from the past, playing the politics of 'victimology' - the politics that is based on the memory of past ethnic tensions. These elements have a restraining effect on the emancipation of the individual. When students are firmly coached to define themselves as nothing but ethnic entities, their scopes are restricted to doing things without upsetting ethnic norms. Although students might not be parts of the traumatic past themselves, they are nevertheless psychologically dragged back into historically remote ordeals of their ancestors.

Secondly, though the EPRDF's educational system does not openly discourage reason and future-directed thinking, students are under severe material, linguistic and psychological limitations to realize their potential. In a normal situation, it is essential for students to have enough understanding of their cultural, linguistic and political roots. The problem with EPRDF's system, however, is that the curricular philosophy is based on unhelpful assumptions. For one, its main concern is ethnicization, where it is thought that ethnic groups are homogenous and members have similar interests. For another, the ethnic groups' past, including traditions, cultures, proverbs, religious systems and art, is approached a seemingly uncritical manner. With little or no room for self-critiquing, the histories of the ethnic groups are presented in such a way as to put the whole blame on others for the past failures. In such a situation, the natural outcome for the young minds in school is resentment and suspicion towards the 'other'. For example, the fear of xenophobia could createa situation in whichyoung students from one ethnic group are fearful of going to other regions. 
Thirdly, Ethiopia is a deeply religious nation still with profoundly embedded legend that created certain national consciousness. Therefore, uncriticallysecularising agenda may not comport well with social and cultural currents. Consider an example from the 'new' Ethiopian constitution. This constitution declares Ethiopia a secular State. For some, this is good news - at least, at face value - because people need not be worried about external persecution because of their choice of religious commitment. However, secularization has presented politicians and teachers with a mammoth challenge. On the one hand, there is burgeoning religious plurality menacing to explode underneath. Meanwhile, the public ethos is laden with ethnic (over against national) consciousness. On the other hand, the principle of secularization does not allow the use of religious elements to channel public ethos. This is because the public sphere, it is deemed, should be empty of religious sentiments. Having a deeply religious and abundantly plural society at their disposal, schools, political leaders and policy makers do not seem to have a viable tool to deal with this tension. It has to be acknowledged, therefore, that the secularizing tendency seems to have created a significant gap in various social pockets such as between citizens and government as well as students and schools. This is because by undermining the legend that used to glue the nation together forced secularization appears to have adversely affected the communication channel between ordinary people and the government. To put it differently, in Ethiopian culture, invoking the legend, for example, is an important social skill. By overlooking the legend as a social skill, because it sounds religious, secularisingeffort creates a gulf, as it were, between students who are coming from religious families and schools which pretend to put religious identity aside. By this I am not suggesting that the academic institutions should be converted into religious entities. However, inasmuch as religion and the legend it created are considered to be irreducible cultural conditions, there should be a non-militant away to incorporate it in academic curriculum.

In conclusion, if the EPRDF is genuinely trying to democratize by re-orientating young minds to their ethnic past, then the course does not seems to be on a practicable track. One can hardly see a viable alliance between ethnic decentralization and democratization. This is because, as Poluha pointed out, 'It entails enhancing the norms, values, and history homogeneity of one's won group'. But, according to Poluha, there is more to it: '[...] by its own logic such behaviour means repressing the rights of minorities even within their own areas, because there is no place on majority ethnic groups' agenda for minorities' (Poluha 1998: 39). The implication of trying to democratize, if that is the intention at all, by way of ethnicizing to educational philosophy is ironic. That is, by producing social pockets which are over-sensitized by ethnic consciousness, not only that it compromises national unity and peaceful co-existence, but also it recyclesrepressions as well as a sense of being victimized by the groups who claims to have a majority vote.

\section{TezetaVs. Qal-Kidan: Towards a Better Alternative}

From a rather brief characterization I gave above, one can deduce that the problem with Ethiopian educationally system is of acomplex nature. The EOC educational system easily grabs the indigenous legend. As a result, it has a cementing effect on the students. However, after some impressive success in its early stage, it lost its innovative dimensionbecause of its increasingly archaic nature and its commitment to a dualistic philosophy. The Dergue tried to catch up with innovative dimension by employing science as the absolute solution. However, its ambitions were damaged not only by its repressive nature, but also its failure to reconcile itself with indigenous legends. EPRDF, on the other hand, tried odd combinations of past-oriented outlook with innovation, democratization with ethnic decentralization and secularization with cultural and religious pluralism. The consequence, as I pointed out, is while the innovative side may bear some fruit, the divisive aspect could easily create social and political instability. In this section I will discuss the question of whether there are any scholarly solutions to these problems. After discussing MaimireMennasemay's recommendation, I will present my own alternative.

In the same vein with handful of notable Ethiopian scholars (such as MessayKebede, PaulosMilkias, and FikreTolosa), Maimire, an Ethiopian philosopher, also questions the cultural validity of the applications of foreign methodologies within the Ethiopian schooling system. The consequence, he argues, has caused a rift within Ethiopian culture and its history. In order to avoid the supposed rift, he suggests, indigenous methods and philosophy should be given a leading role. He then goes on to propose a specific and intriguing conceptual tool to be used as a background legend to educational philosophy in Ethiopia. The solution to the supposed Ethiopian educational crisis, Maimire argues, can only be found in the Ethiopian 'surplus-history' - the underlying national consciousness that is created by the adherence to concepts that are not officially recognized as actual or manifest national history. An example of this, according to Maimire, is an indigenous motif known as tezeta (nostalgia). Tezeta is not educational philosophy per se. It is a musical style with its own unique genre. As a motif which mainly deals with time concept, it aims to reinvent 'the old good days'. This musical motif, Maimire thinks, could serve also as an effective philosophical tool to construe Ethiopian educational philosophy. The reasons are, firstly, he thinks tezeta has a popular appeal. This is because full of symbolism and allegory tezeta can enthrall every Ethiopian 
irrespective of class, gender, religion, age and ethnic difference (Maimire 2010: 87).

Secondly, according to Maimire, tezeta can generate strong desire for utopia. He does this by way of de-regionalizing tezeta from the realm of fantasy, and introducing a seemingly contrasting concept: minab - a concept which, according to Maimire, denotes 'abstract utopia' - wishful thinking and daydreaming. On the contrary, Maimire argues, tezeta has to do with a 'concrete utopia' or real history. He proposes tuning the Ethiopian education system along the line of tezeta motif helps Ethiopians to be connected to the anticipatory dimension of Ethiopian surplus-history. 'When we discover our music as an integral part of our history', he remarks, 'we rediscover in its voice the unfulfilled hope of the past, the sufferings of the present, and the promise of the possible bright future'(Maimire 2010: 86). The reason, according to Maimire, is that tezeta has tri-dimensional nature in which the past, present and future are intertwined. Rendered into education, tezeta "expresses suffering and hope of the "we" of surplus-history: the peasantry, the unemployed, the poor, the marginalized, the workers, the excluded and the oppressed' (Maimire 2010: 86). The 'historical content of hope', Maimire goes on to suggest, generates a militant desire demanding emancipation in forms of rebellion, regional uprising, banditry, etc. Only then, Maimire concludes, can we achieve self-intelligibility as Ethiopians, and can we 'ensoul' modern education and repatriate Ethiopian educational philosophy from present 'exile'.

We have to ask how far Maimire's proposal comes as a solution to the problems I mentioned earlier. Doubtless, there are merits to Maimire's proposal. For example, the use of tezeta can help students to connect to a certain indigenous legend and avoid unfruitful foreign elements of educational philosophy. Besides, tezeta as a motif that runs through all ethnic groups can create the much needed 'we' of surplus history and create an overarching narrative over against ethnic fragmentation. Still, his proposal leaves one wondering: does tezeta have a potential that is attributed by Maimire? Intrigued by Maimire's argument, I could not help but try to collect and listen to a number of tezeta songs performed by prominent singers such as Mohamoud Ahmed (also dubbed as the king of tezeta), Kuku Sebsebe, AlemayehuEshete and MadingoAfework. True to Maimire's argument, tezeta is full of symbolism and allegory. It as well has a potential to generate immense desire to be re-connected to the triumphal past. Doubtless, many Ethiopians would easily find these aspects of tezeta enchanting. However, tezeta has clear limitations should it be used as the grounds for educational philosophy. Firstly, tri-dimensionality as a balanced consideration of the past, present and future that Maimire attributed to tezeta is indeed of crucial importance for educational philosophy. However, all the songs I listened seem to militate against Maimire's claim of tri-dimensionality of tezeta. However, the nature of tezeta motive does not show this balance in relation to the concept of time. Instead, the past is romanticized. In fact, the songs express a powerful nostalgia to things as they were. In sharp contrast, they put forward their utter dissatisfaction with things as they are at present. Knowing actual impossibility of being transposed to the past, people use tezeta as vehicle for a fantasy journey back into history.The future therefore is almost non-existent. The implication of this is that tezeta is not tri-dimensional. It rather is an expression of a desire to imaginary reinvention of the glorious past.

Certainly there is a utopian element to tezeta. However, yet again, this utopianism is not future-oriented. Rather it is about recreating, albeit in minab (idealistic reconstruction), the glorious past. So tezeta is necessarily one dimensional in a sense that it is a motif in which present is dominated by the past. In this way, tezeta has a power that discourages and/or restrains the desire to create a better future. Consider an example from Madingo's song in which he ironically criticizes tezeta using the same style. Of the people who make tezeta the epicenter of their lives, he sings:

Yehew sew yenoral be tezetasebeb

Yehualitsigalebtenantenbemaseb

Translation: Look at the people who are smitten by tezeta

Galloping backwards, craving for yesterday.

He then wonders:

Sew endetbalefewbetenantyenoral

Zarenbeejuyezolenegewmeselal

Translation: How is it possible for anybody to dwell on yesterday (the past), While today is at hand, a ladder to reach tomorrow (the future)

Secondly, the fact that the tezeta motif is full of symbolism, allegory and indirection makes the task of overcoming unhelpful dualism between 'sacred' and 'material' very difficult. There is nothing wrong about symbolism and allegory per se. However, the dualism that characterizes Ethiopian society has an adverse effect, at least, on social 
practices. For example, as I tried to demonstrate elsewhere, the sem-ena-werq (wax and gold) tradition of playing with double-layered meaning has made communication at different levels full of indirection, suspicion and ambiguity (Girma 2010: 182-3). Functioning from identical system of indirection and ambiguity, tezeta therefore, has severe limitations to transform educational system while preserving its aesthetic aspect. Applying tezeta as an educational philosophy comes with a risk of jeopardizing important attribute of science such as clarity, precision and objectivity.

Thirdly, as an important source of entertainment, tezeta remains relevant for every Ethiopian. However, its relevance outside aesthetic domain is circumscribed to a therapeutic purpose for people who are disgruntled with the present state of affairs. For instance, individuals who have made remarkable contributions in terms of preserving unique civilization, defending the nation from foreign occupation and preserving freedom with the dearest of prices may feel nostalgic about the time in which they were at their best. In this vein, they might consider the present political, economic and social state of affairs as something less than desirable. Tezeta then not only provides them with a means to release their quchit (frustration), but it also connects them to their happy past. However, there seems to be no compelling justification for orientating young generation on tezeta, if the intention is to take them to their potential future. This is because tezeta, at its best, can only gear young students towards contentment with and pride in the glorious past of forefathers instead of helping them to make even better future of their own.

I share with Maimire the sentiment that Ethiopian educational system should be based on Ethiopian culture and way of life. That is the reason why I chose to suggest the imperativeness of grounding Ethiopian education in an indigenous legend. Moreover, I concur with his argument that indigenous concepts which created surplus-history in Ethiopia are of crucial importance in reformulating educational philosophy. I, however, opt to choose a different legend which, I contend, is more viable than tezeta - qal-kidan (literally means covenant). What is qal-kidan? Where did it come from? How can it serve as a better basis for educational philosophy? Originally, this notion of qal-kidan has a religious, especially a biblical, root. Particularly, the legend arises from the fact that the name 'Ethiopia' is mentioned in the Bible several times. This notion, however, transformed itself into a powerful ideological tool in fourteenth century when anonymous author wrote a book called KebreNegest (glory of Kings).

The writer apparently had deep-seated theo-political agendas. On the one hand, after the twilight of the Zagwe dynasty, which interrupted Solomonic dynasty from about 1117-1270, the national unity of Ethiopia was at risk. There was a number of infighting among the provincial political leaders over power and regional control. Related to this, Ethiopia's standing in the world (especially in the Middle East) was in danger of slipping away because of internal strife and the absence of unifying political figure. The best remedy for this, according to the author of KebreNegest, was restoring Solomonic dynasty. In order to achieve this, the author knew there had to be an established legend that could tap into religiosity of the society, and yet, able to serve as an effective tool of political propaganda. So he formulated a legend in such a way as to re-educate the mass, but also to convince provincial leaders to stop internal squabbling and unite under one central monarch.

In order to achieve this, KebreNegest re-interpreted Scriptural accounts, especially the story of the Queen of Sheba and King Solomon, in a manner that could, first, connect Ethiopia to ancient Israel, and second, link Ethiopian kings to Solomonic bloodline. It tells then a griping love story between the Queen and the King. Queen's visit then ended up with leaving to her home (after paying a visit to King Solomon) carrying his seed in her womb, who later became king Melelik I. That sets off the starting point of Solomonic dynasty. The central in both cases is the Tabot (the Ark of Covenant), which was supposedly given by Solomon to his alleged son Menelik I to be taken to Ethiopia. Tabot therefore is something that not only justifies the Jewish origin of the Ethiopian state (TibebeEshete 2009: 19), it also became a divine object that brings Ethiopia's mystical past and prophetic feature together (John Markakis 2004: 45). The ultimate argument of KebreNegest, therefore, is that Ethiopia, because of espousing the Ark, embracing Christianity as state religion and having kings descended from Solomonic line, has become a new Israel - a center of divine attention. For the Ethiopians, the legend and the covenant-thinking it established became 'the genuine experience and the cannon through which they construe their history, social organization, and national destiny' (Messay 1999: 78). Permeating every department of life, this became, in Edward Ullendorff's words, 'a repository of the cultural, political and social life of the country' (Ullendorff1956: 216).

This legend has two layers. I will explain this by way of utilizing Maimire's notion of manifest (or actual) and surplus history. In manifest history, the legend was a creation of political as well as ecclesiastical elites. It, in fact, was used to unify the nation under one monarch who was deemed to be an heir of King Solomon. Furthermore, the legend puts a clear limitation on who should aspire for political leadership. In other words, kings used the legend not only to preserve their ideology, but also to constrict political power to a certain elite group. However, in surplus history, the legend with its covenant-thinking boils down into something else. There are two things that I need to clarity here. Firstly, it is imperative to be mindful of the fact that the main actors in manifest history are political 
elites while it is ordinary people in surplus history. Secondly, it is important to know that there is considerable philosophical difference in the use of qal-kidan among the political elites and ordinary people. That is, for the former, the legend is a political selling point used for practical reasons such as unifying the nation. For the latter, qal-kidan is a metaphysical imperative. This is precisely because their world is built in relationships. This relationship, as I tried to establish elsewhere, has three dimensions: spiritual (with God), social (with fellow human persons) and ecological (with nature) (Girma 2009: 496). At this level the legend of qal-kidan is not about political power. It instead is about ordinary people using it as a way of responding to a presumed divine call for a responsible relationship and harmonious coexistence. Ethiopian history shows, time and again, that the legend helped them to overcome ethnic differences as well religious barriers. This is because among the ordinary people qal-kidan is not only about tolerating difference, but it is also about accepting them. It is a living testimony of this fact that Ethiopia is one of the few nations in which Christians and Muslims peacefully coexisted for centuries with no major clash between them (Ulrich Braukamper 2004: 4). This is because the legend created a culture in which people feel they are answerable and covenanted to fellow Ethiopians regardless of religious commitment, ethnic and linguistic backgrounds.

Therefore, there are several compelling reasons for giving the primacy of qal-kidan over tezeta as a basis for educational philosophy. Firstly, its proven ability to glue diverse Ethiopian society together means that qal-kidan condemns injustices in a more forceful and unambiguous way than tezeta does. That brings fairness but also social cohesion to educational atmosphere. Unlike tezeta, it does not approach the present state of affairs with resentment; neither does it foster a desire to fly back to the past to escape the supposedly dismal outlook of present time. Rather, it looks for a positive ground on which to execute present actions to realize the promise or the potential lying ahead in the future. Nevertheless, it honors the past because it is the root, the beginning and the origin without which it is hard to fully grasp both present and future. In fact, instead of dwelling in it, it takes the success stories in the past as source of motivation to achieve even better.

There is more to qal-kidan's relation to nature: it takes nature as abundantly rich and full of untapped economic but also spiritual potential. Human relation to nature includes a mandate to use and take a good care of it. Outsourcing the nature in qal-kidan culture comes with the risk of upsetting relational structure which is essential to the existence of society. One could surmise then: how can this explain the fact that Ethiopia, in the past decades, is a heavily deforested country? My argument is that the sole factors for a heavy deforestation are not only natural and economic ones. Philosophical shift has also a lion share. That is, until the Dergue, nature is considered to be a part of sacred order. The Dergue came up with a narrative that demystified the nature. Such a secularist stance brought down the nature from the sacred order to the material order creating an impression that nature is principally owned and managed by human agencies such as the state. Understandably, whenever people are frustrated with their political leaders, such a philosophy of nature made people vent their anger on nature. This is because the relegation of the sacred order from public understanding means that the state owns the nature.

Consider an example from heavily deforested areas in the Northern part of Ethiopia. After passing through an immensely deforested area, if one comes across to a small plot of land covered with bushes and trunk of trees, one can safely think there is a church or some religious institution in the middle. Now the question is: why do the people spare the trees near to a church while cutting down trees in other areas? Unambiguous answer is that people believe that the trees near to a church are under the sacred order. Therefore outsourcing trees nearby 'holy' places, they believe, would upset their relations to the sacred realm. This implies that reinterpreting and redirecting the qal-kidan framework can be a helpful tool to restore the respect to and responsibility towards nature. In doing so, it promotes exploration, discovery and disclosure, and yet, it orientates students to approach nature with a sense ofcare and stewardship.

Secondly, the legend of qal-kidan addresses one of the main problems in Ethiopian education that Maimire does not particularly raise: the lack of the sense of vocation. Etymologically, vocation comes from a Latin word vocatio which literally means 'calling'. Ethiopia is a society where professions are understood in a hierarchical fashion. There are professions that are traditionally considered as 'noble'. This includes, but is not limited to the positions as administrator/manager, politician, artist, medical expert, etc. But there are others, such as blacksmiths, weavers, clay makers, who do their work at the expense of their dignity as humans. In fact, by the virtue of carrying out their professions, they are made into social outcasts. On the other hand, the regimes often use education as an ideological tool by which the governing establishment striped students of their sense of vocation. In fact, less ideologically laden subject, yej sera (craftsmanship), was the most overlooked course in the school.

Moreover, both unconstructively conservative tradition and bad governance seem to have blurred the sense of calling to a particular vocation in academic pursuit. As a result, students have very limited chance, if any, to identify their callings. That means that a student who has an inner call - by this I mean unique capability - as a very skillful 
entrepreneur ends up being a politician. A politician on the other hand ends up being a preacher. Despite some of these havesufficient training, they find themselves doing something that is not inherently fitting to their inner call. For example, the entire generation that was involved in the revolution went through the same track. Instead of rallying the whole generation behind the motto of meretlarash (land to the tiller), delegating some to other mottos such as wehalegeberew (water to the farmers) would have taken the society into a different trajectory. In stark contrast to this situation exploring, enriching and exploiting the inner call is of crucial importance to the philosophy of qal-kidan. That means that, in the actual learning situation, the qal-kidan-thinking strives to empower students to overcome this educational disarray by helping individual students to search for a particular promise within themselves so that they can maintain their unique individuality and follow their own vocation.

Finally, unlike tezeta which, according to Maimire, might use social uprising, rebellion and even banditry as a way of demanding change, qal-kidan-thinking emphasizes responsibility as an important criterion. Responsibility in the context of educational philosophy means, avoiding utopian revolution, which, in the past, only made Ethiopians suffer with undue sense of martyrdom for the cause of the revolution. Yet, like Maimire, it wants to connect to 'the unfulfilled hope of the past, the sufferings of the present, and the promise of the possible bright future' (Maimire 2010: 78), which is implied in Ethiopia's surplus-history. But unlike Maimire's proposal, it relates these elements to the rich potential of nature and to the actual conditions of the present.

That means, the problems I raised can be overcome, for one, by openness to the fruits of modernity and modern education. Yet, it must be buttressed by a viable indigenous legend and grounded into the Ethiopian identity. This is because qal-kidan takes the embedded cultural as well as individual potentials as its starting-point, not a supposedly glorious past. Therefore the qal-kidan legend does not look backwards; it rather opens itself up to positive development in the future. For another, the qal-kidan framework can be used to overcome philosophical dualism unproductively dichotomizing between sacred and material. This is precisely because the philosophical ground of this legend suggests that all spheres of life are considered to be of value and each individual talent is respected.

\section{Concluding Remarks}

I made an effort in this essay to show the roots of the alleged 'crisis' in Ethiopian education. The obvious obstacle for a healthy growth of education in Ethiopia comes from ideological intrusion of the regimes in the sphere of education. Despite a certain level of freedom under some regimes, the sphere of education has often fallen prey for the ruling eliteswhotry to infuse their ideology in educational system as a means of survival. However, the main source of problem with Ethiopian education is the impotence of the system to look and ground its educational philosophy in a viable indigenous legend. I here reflected growing scholarly dissatisfaction by the native educators and a call to ground Ethiopian education in Ethiopian soil. I then discussed tezeta as a ground for educational philosophy - a proposal put forward by Maimire. After showing the limitations of tezeta, I presented my own alternative - qal-kidan. At the end, qal-kidan, I have to concede, may not be a golden parachute. Given how the notion, and the legend, have been hijacked by political elites and religious ideologues, I'm aware that it requires a careful re-interpretation and redirection. Provided this, however, this seems to be the notion that can tap into the core of 'etiopiawinet' (Ethiopian-ness) in such a way as to mobilize people to reset homegrown innovative spirit.

\section{References}

Allen, D. (1985). Philosophy for Understanding Theology. London: Westminster John Knox Press.

Armstrong, H. (1967). Cambridge History of Later Greek and Early Medieval Philosophy. Cambridge: Cambridge University Press.

Braukamper, U. (2004). Islamic History and Culture in Southern Ethiopia: a collection of essays. Munster: Lit Verlag.

Bushell, W. (1995). 'Psychological and Comparative Analysis of Ascetico-Meditational Discipline: Towards a New Theory of Asceticism' in V. Wimbush and R.Valantasis eds. Asceticism. Oxford: Oxford University Press.

Chaillot, C. (2002). The Ethiopian Orthodox Tewahedo Church Tradition: a brief introduction to life and spirituality. Paris: Inter-Orthodox Dialogue.

Clegg, S., \& C. Hardy (1999). Studying Organization: theory \& method. London: Sage Publications.

Ferenc, A. (1985). "Writing and Literature in Classic Ethiopic (Giiz)". In: B. W. Andrzejewisky et.al. (eds.), Literature in African Languages: theoretical issues and sample survey. Cambridge: Cambridge University Press.

Getachew Metaferia (ed.), The Battle of Adwa: Reflections on Historic Victory Again. New York: Algora Publishing.

Girma M. (2010). The Interplay between Religion and Society in Ethiopia: towards a hermeneutic of covenant.Ph.D. Thesis, VU University of Amsterdam. 
Girma M.. (2011). 'Whose Meaning?: The Wax and Gold Tradition as a Philosophical Foundation for Ethiopian Hermeneutics' in Sophia: International Journalfor Philosophy of Religion, Metaphysical Theology and Ethics. V.50, Number 1 (2011)175-187

Goudzwaard, B., \& V. Mark (2007). Hope in Troubled Times: a new vision for confronting global crises. Grand Rapids, MI: Eerdmans.

Levin, D., (1974). Greater Ethiopia: the evolution of multiethnic society. Chicago: University of Chicago Press.

Levinson, D. \& P. Cookson (2002). Education and Sociology: encyclopedia. London: Taylor and Francis.

Maimire M. (2005). ‘Ethiopian History and Critical Theory'in: PaulosMilkias\&

Maimire M. (2010). 'Towards a Critical Theory of Ethiopian Education' in P. Milkias and M. Kebede (eds.), Education, Politics and Social Change in Ethiopia. Hollywood, CA: Tsehai Publishers.

Markakis, J. (2004). Ethiopia: anatomy of traditional polity. Addis Ababa: Shama Books.

Marrow, R. and C. Torres (1995) Social Theory and Education: a critique of theories of social and cultural production. New York: SUNY Press.

Mercier, J. (2001). 'Ethiopian Art History', in Deborah E. Horowitz et. Al. (eds.), EthiopianArt: The Walter Art Museum. London: The Third Millennium Information, Ltd

Messay K. (1999). Survival and Modernization: Ethiopia's enigmatic present: a philosophical discourse. Asmara: Red Sea Press.

Messay K. (2008). Radicalism and Cultural Dislocation in Ethiopia, 1960-74. New York: University of Rochester Press.

Moges Y. (2010). Language Ideologies and Challenges of Multilingual Education in Ethiopia: the case of Harari region. Addis Ababa: OSSREA.

Poluha, E. (1998). 'Ethnicity and Democracy - A Viable Alliance?', in Mohammed Salih\& John Markakis (eds.), Ethnicity and the State in Eastern Africa. NordiskaAfricainstitutet: Stockholm.

Poluha, E. (2004). The Power of Continuity: Ethiopia through the Eyes of Its Children. NordiskaAfricainstitutet: Stockholm.

Saint, W. (2004). 'Higher Education in Ethiopia: The Vision and Its Challenges'. JHEA/RESA Vol. 2, No. 3, 2004, pp. $83-113$

Tekeste N. (1996). Rethinking Education in Ethiopia. Uppsala: NordiskaAfrikainstitutet, University of Uppsala.

Tekeste N. (2006) Education in Ethiopia: From Crisis to the Brink of Collapse. Uppsala: NordiskaAfrikainstitutet.

Tekeste N. (2010). 'The Curse of English as a Medium of Instruction in Ethiopian Education System'. In: PaulosMilkias and MessayKebede (eds.), Education, Politics and Social Change in Ethiopia. Hollywood, CA: Tsehai Publishers.

Tibebe E. (2009). The Evangelical Movement in Ethiopia: resistance and resilience. Waco, Texas: Baylor University Press.

Turner, F. (1991). Rebirth of Value: Meditations on Beauty, Ecology, Religion, and Education.New York: SUNY Press.

Ullendorff, E. (1956). 'Hebraic-Jewish Elements in Abyssinian (Monophysite) Christianity', in Journal of Semitic Studies (1956) 1 (3):216-256.

Usher, R., \& Edwards, R. (1994). Postmodernism and Education: Different Voices, Different Worlds. London: Routledge., 